\title{
Antidiarrhoeal effects of Mikania glomerata Spreng. (Asteraceae) leaf extract in mice
}

\author{
Hérida R.N. Salgado*, Ana Flávia F. Roncari, Raquel R.D. Moreira \\ Faculdade de Ciências Farmacêuticas, Universidade Estadual Paulista, Rodovia Araraquara-Jaú, km 1, \\ 14801-902, Araraquara, SP, Brasil
}

\begin{abstract}
Mikania glomerata Spreng. (Asteracae) is a plant widely used to treat gastrointestinal disorders in Brazilian traditional medicine. In the present work, an aqueous extract of the leaves of Mikania glomerata has shown a decrease in the propulsive movements of the intestinal contents in mice. Oral administration produced an inhibition of gastrointestinal transit as effective as that produced by loperamide. These findings suggested that the aqueous extract of the leaves of Mikania glomerata might elicit an antidiarrhoeal effect by inhibiting intestinal motility.
\end{abstract}

Keywords: Mikania glomerata, Asteraceae, guaco, intestinal motility.

\section{INTRODUCTION}

The World Health Organization (WHO) had established a special program for the Control of Diarrhoeal Diseases in the last two decades (WHO, 1994).

The majority of the world's population in developing countries still relies on herbal medicines to meet their health needs. Brazil has a great environmental and biological diversity compared with the rest of the world.

Mikania glomerata Spreng. (Asteraceae), popularly known as "guaco", is an herbaceous creeper and climbs over shrubs and trees. M. glomerata, commonly found in Brazil, is used in Brazilian folk medicine due to its respiratory tract effects (Penna, 1930). Moreover it is also used to treat cold, flu, fever, and rheumatism (Neves; Sá, 1991; Sá et al., 2003). It has been used in commercial preparations. The plant has local reputation as analgesic (Ahmed et al., 2001), antimutagenic (Arias et al., 1995), insecticidal (Arias et al., 1995), trypanomicidal (Arias et al., 1995, Muellas-Serrano et al., 2000), nutritive (Baidya et al., 1995); anticarcinogenic (Bishayee; Chatterjee, 1994), antiallergic (Fierro et al., 1999), antimicrobial (Hufford et al., 1998), and antiulcer (Paul et al., 2000) to Mikania sp. So far, some phytochemical studies had been reported on the kaurenoic and cinamoilgrandifloric acids, di and sesquiterpenes (Vilegas et al., 1997; Rüngeler et al., 2001), coumarins (Vilegas et al., 1997; Veneziani; Oliveira, 1999; Cabral et al., 2001), flavonoids and stigmasterol(Aguinaldo etal., 2003). Many phytochemical studies on Mikania species are described in the literature (Aguinaldo et al., 2003; Ahmed et al., 2001; Bardón et al., 1996; Bohlmann et al., 1981; 1982a e 1982b; Castro et al., 1989; Cruz; Roque, 1992; Cuenca et al., 1988, 1992, 1993; Diaz et al, 1992; Fabbri et al., 1997; Gutierrez et al., 1985, 1987, 1988; Herz et al., 1975; Herz; Kulanthaivel, 1985; Kiang et al., 1968; Knudsen et al., 1986; Lobitz et al., 1997, 1998; Nicollier; Thompson, 1981; Nunez et al.,
2004; Ohkoshi et al., 2004; Reis et al., 2003; Rungeler et al., 2001; Silva et al., 1984; Veneziani; Oliveira, 1999; Zamorano et al., 1995).

The present work was carried out to evaluate the anti-diarrhoeal potency of the aqueous leaf extract of $M$. glomerata Spreng. (Asteraceae) using intestinal motility test as experimental model in mice.

\section{MATERIAL AND METHODS}

\section{Plant material}

Fresh leaves of Mikania glomerata were collected in the Herbarium of Medicinal Plants of the Faculdade de Ciências Farmacêuticas da UNESP in Araraquara, São Paulo, Brazil and have been kept in our laboratory for future reference. Botanical identity was kindly authenticated by Dr. LVS Sacramento of the Department of Active Natural Products - FCF - UNESP - Araraquara and a specimen of the plant has been deposited in the University Herbarium.

\section{Preparation of aqueous extract}

The plant material was air dried and then ground with $5 \mathrm{~mm}$ diameter mesh. The air-dried plant material was powdered through a $2 \mathrm{~mm}$ screen in a Wiley mill. The ground plant material was sequentially extracted by exhaustive maceration at room temperature with ethanol and water. The supernatants were filtered and evaporated under vacuum to obtain the aqueous extracts. The leaves aqueous extract was evaporated on a rotary evaporator and then reconstituted with sterile water $(100 \mathrm{mg} / \mathrm{mL})$.

Test for gastrointestinal motility (charcoal meal) in mice

Forty adult female Albino Swiss mice (Mus 
Table 1. Effect of orally administered $1000 \mathrm{mg} / \mathrm{kg}$ of Mikania glomerata aqueous extract on gastrointestinal motility in mice

\begin{tabular}{lc}
\hline \multicolumn{1}{c}{ Treatment } & Distance of charcoal (\%) \pm S.D. \\
\hline Control (veicule) & $77.52 \pm 8.97$ \\
Loperamide hydrochloride $(5 \mathrm{mg} / \mathrm{kg})$ & $62.34 \pm 11.21^{*}$ \\
Mikania glomerata aqueous extract $(1000 \mathrm{mg} / \mathrm{kg})$ & $66.99 \pm 10.60^{*}$ \\
Mikania glomerata aqueous extract $(500 \mathrm{mg} / \mathrm{kg})$ & $77.41 \pm 9.24$ \\
\hline
\end{tabular}

Values are mean \pm S.D., $\mathrm{n}=10$ (per group),

$* P<0.05$ vs. Control, Student's $t$-test

domesticus domesticus), weighing between 24-30 g were selected and housed in polypropylene cages (30 x 20 $\mathrm{x} 13 \mathrm{~cm})$ in standard conditions $\left(21 \pm 1^{\circ} \mathrm{C}\right.$ with a $12 \mathrm{~h}$ reversed light-dark cycle and relative humidity 50-60\%) for 10 days before performing the experiment. There was free access to water and normal commercial laboratory diet (Purina, Brazil). Experiments performed complied with the rules of the Institute of Laboratory Animal Resources, Commission on Life Sciences, and approved by the Ethical Committee of the Faculdade de Ciências Farmacêuticas - UNESP (Araraquara, São Paulo, Brazil - Protocol number 24/2004).

In the day of the test the animals were divided into four groups of ten mice each. They were weighed and deprived of food, with free access to water. Three hours after food deprivation the animals in treated groups (A and B) received orally $M$. glomerata extract (100 $\mathrm{mg} / \mathrm{mL}$ ) by gavage 500 and $1000 \mathrm{mg} / \mathrm{kg}$, while controls groups received $0.9 \% \mathrm{NaCl}$ sterile solution (Wong; Way, 1981; Olajide et al., 1999) and positive control group was given loperamide $(5 \mathrm{mg} / \mathrm{kg})$ as a reference antidiarrhoeal drug.

Ninety minutes after administering the extracts, $0.3 \mathrm{~mL}$ of a $5 \%$ charcoal suspension in $10 \%$ aqueous suspension of charcoal powder was administered to each animal orally. The animals were sacrificed 45 min later in $\mathrm{CO}_{2}$ chamber and the abdomen opened. The percentage distances of the small intestine (from the pylorus to the ceccum) traveled by the charcoal plug were determined. The method was described by Janssen; Jageneau (1957) and Wong; Way (1981).

\section{Statistical analysis}

The results are expressed as means \pm S.D. Statistical significance was tested using a Student $t$-test. A difference was taken to be significant at $P<0.05$.

\section{RESULTS AND DISCUSSION}

The standard method has used 18 - 24 h food deprivation and then the animals were given an aqueous suspension of charcoal that causes animal stress (Janssen; Jageneau, 1957). These authors described the intestinal motility experiment using overnight fasted animals. In our protocol animals are deprived of food during $3 \mathrm{~h}$ (Marona; Lucchesi, 2003). Our project is in agreement with the new concept and it is important for a respectful science.

Vermullen et al. (1997) observed rats with food deprivation. An experimental group of rats showed a decrease of $-5 \%$ in body weight after 6 -h fast. These animals showed $-11 \%$ of liver weight. The 12-h deprived animals showed a decrease of $-9.1 \%$ in body weight and $28 \%$ of liver weight. The third experimental group showed a $-13 \%$ in body weight after 18 -h fasting and $-31.8 \%$ of liver weight. These observations could be a result of excessive stress caused by long fasting periods (Laties, 1987). Our work suggests only 3 hours of fasting before the experiment. This reduced time allows an experimental research carried out with non-stressed animals that could improve animal welfare and also increase the quality of science.

Our results suggest that $M$. glomerata aqueous extract showed lower percentages in small intestine distance in comparison with control group. In addition to providing promising new leads to the ongoing search for new drugs, the data analysis from this research has also suggested how future pharmacological investigation and ethnobotanical literature can be useful in guiding researches.

The distance of traveled by the charcoal plug is showed in Table 1. It is possible to compare that $M$. glomerata leaf extract $(100 \mathrm{mg} / \mathrm{kg}$ ) reduced significantly the distance of the charcoal marker in the feces compared with control group.

From this preliminary study this species was selected because of its intensive distribution in markets for gastrointestinal disorders and because it was available in good quantity in our laboratories.

Intestinal diseases are one of the main causes of death of infants particularly in developing countries 
(WHO, 1994). It thus becomes important to identify and evaluate commonly available natural drugs as an alternative to currently used anti-diarrhoeal drugs.

In this protocol animals were deprived from food during a short time (3h) in agreement with Animal Welfare Guidelines as described by Marona and Lucchesi (2003). This short-time reduces aggression between mice and may be promoted as being beneficial to their physical and psychological health.

The results of this research reveal that the aqueous leaf extract of Mikania glomerata contains pharmacologically active substances(s) with antidiarrhoeal properties. This aspect may explain the use of Mikania glomerata as an antidiarrhoeal agent in popular medicine.

\section{ACKNOWLEDGMENTS}

We would like to thank L. R. Araújo and L. E. Santos for technical support. HRNS was funded by CNPq-Brazil. This work was financial supported by PADC-FCF-UNESP.

\section{REFERENCES}

Aguinaldo AM, Padolina WG, Abe F, Yamauchi T 2003. Flavonoids from Mikania cordata. Biochem System Ecol 31: 665-668.

Ahmed M, Rahman MT, Alimuzzaman M, Shilpi JA 2001. Analgesic sesquiterpene dilactone from Mikania cordata. Fitoterapia 72: 919-921.

Arias AR, Ferro E, Inchausti A, Ascurra M, Acosta N, Rodriguez E, Fournet A 1995. Mutagenicity, insecticidal and trypanocidal activity of some Paraguayan Asteraceae. $J$ Ethnopharmacol 45: 35-41.

Baidya N, Mandal L, Banerjee GC 1995. Nutritive values of Mikania scandens and Erythrina indica in Black Bengal goats. Small Ruminant Res 18: 185-187.

Bardón A, Cardona L, Catalán CAN, Pedro JR 1996. 15Norguaianolides and germacranolides from Mikania mendocina. Phytochemistry 41: 845-849.

Bishayee A, Chatterjee M 1994. Anticarcinogenic biological response of Mikania cordata: reflections in hepatic biotransformation systems. Cancer Lett 81: 193-200.

Bohlmann F, Adler A, Schuster A, Gupta RK, King RM, Robinson H 1981. Diterpenes from Mikania species. Phytochemistry 20: 1899-1902.

Bohlmann F, Adler A, King RM, Robinson H 1982a. Germacranolides from Mikania grazielae. Phytochemistry 21: 1169-1170.

Bohlmann F, Singh P, Jakupovic J, Robinson H, King RM 1982b. An epoxygermacranolide and further constituents from Mikania species. Phytochemistry 21: 705-707.

Cabral LM, Dos Santos TC, Alhaique F 2001. Development of a profitable procedure for the extraction of 2-H-1benzopyran-2-one (coumarin) from Mikania glomerata. Drug Dev Ind Pharm 27: 103-106.

Castro V, Jakupovic J, Bohlmann F 1989. Germacranolides from Mikania species. Phytochemistry 28: 527-530.
Cruz FG, Roque NF 1992. Diterpene acids from Mikania triangularis. Phytochemistry 31: 2793-2796.

Cuenca MR, Bardon A, Catalán CAN, Kokke WCMC 1988. Sesquiterpene lactones from Mikania micrantha. J Nat Prod 51: 625-626.

Cuenca MR, Borkosky S, Catalán CAN, Diaz JG, Herz W 1992. A cadinanolide and other sesquiterpene lactones from Mikania haenkeana. Phytochemistry 31: 3521-3525.

Cuenca MR, Borkosky S, Catalán CAN, Goedken VL, Diaz JG, Herz W 1993. Sesquiterpene lactones of Mikania minima. Phytochemistry 32: 1509-1513.

Díaz JG, Goedken VL, Herz W 1992. Sesquiterpene lactones and other constituents of Mikania rimachii and Mikania microptera. Phytochemistry 31: 597-608.

Fabbri H, Oliveira DCR, Vichnewski W, Herz W 1997. Diterpenes of Mikania lindbergii baker. Biochem System Ecol 25: 563-564.

Fierro IM, Silva ACB, Lopes CS, Moura RS, Barja-Fidalgo C 1999. Studies on the anti-allergic activity of Mikania glomerata. J Ethnopharmacol 66: 19-24.

Gutierrez AB, Oberti JC, Kulanthaivel P, Herz W 1985. Sesquiterpene lactones and diterpenes from Mikania periplocifolia. Phytochemistry 24: 2967-2971.

Gutierrez AB, Oberti JC, Sosa VE, Herz W 1987. Melampolides from Mikania cordifolia. Phytochemistry 26: 23152320.

Gutierrez AB, Oberti JC, Herz W 1988. Germacran-5,14,6,12diolides from Mikania urticifolia. Phytochemistry 27: 938-939.

Herz W, Sriivasan A, Kalyanaraman PS 1975. Mikanokryptin, a new guianolide from Mikania. Phytochemistry 14: 233237.

Herz W, Kulanthaivel P 1985. Diterpenes and sesquiterpene lactones from Mikania congesta. Phytochemistry 24: 1761-8.

Hufford CD, Meurer-Grimes B, Passreiter CM, Cordero J, Ibrahimi O, Okunade AL 1998. Antimicrobial properties of Honduran medicinal plants. J Ethnopharmacol 63: 253-263.

Janssen P, Jageneau AH 1957. A new series of potent analgesics. Part I - Chemical structure and pharmacological activity. J Pharm Pharmacol 9: 381-400.

Kiang AK, Sim KY, Yoong SW 1968. Constituents of Mikania cordata (Burm. F.) B. L. Robinson (Compositae)-II. Phytochemistry 7: 1035-1037.

Knudsen FS, Vilegas W, Oliveira F, Roque N.F 1986. Pimaradiene diterpenes from Mikania triangularis. Phytochemistry 25: 1240-1242.

Laties V 1987. Control of animal pain and distress in behavioral studies that use food deprivation or aversive stimuli. $J$ Am Vet Med Assoc 191: 1290-1291.

Lobitz GO, Tamayo-Castillo G, Merfort I 1997. Diterpenes and sesquiterpenes from Mikania banisteriae. Phytochemistry 46: 161-164.

Lobitz GO, Tamayo-Castillo G, Poveda L, Merfort I 1998. Kaurene diterpenes from Mikania vitifolia. Phytochemistry 49: 805-809.

Marona HRN, Lucchesi MBB 2003. Refining the intestinal motility test in mice to reduce animal stress. Rev Cienc Farm 24: 79-82.

Muelas-Serrano S, Nogal JJ, Martínez-Díaz RA, Escario JA, Martínez-Fernández AR, Gómez-Barrio A 2000. In vitro screening of American plant extracts on Trypanosoma 
cruzi and Trichomonas vaginalis. J Ethnopharmacol 71: 101-107.

Neves LJ, Sá MFA 1991. Contribuição ao estudo das plantas medicinais Mikania glomerata Spreng. Rev Bras Farm 72: $42-47$.

Nicollier G, Thompson AC 1981. Essential oil and terpenoids of Mikania micrantha. Phytochemistry 20: 2587-2588.

Nunez CV, Amêndola MC, Lago JHG, Roque NF 2004. Diterpene acids from Mikania sp. nov (Asteraceae). Biochem System Ecol 32: 233-237.

Ohkoshi E, Kamo S, Makino M, Fujimoto Y 2004. ent-Kaurenoic acids from Mikania hirsutissima (Compositae). Phytochemistry 65: 885-890.

Olajide OA, Awe SO, Makinde JM 1999. Pharmacological studies on the leaf of Psidium guajava. Fitoterapia 70: 25-31.

Paul RK, Jabbar A, Rashid MA 2000. Antiulcer activity of Mikania cordata. Fitoterapia 71: 701-703.

Penna, M 1930. Notas sobre plantas brasileiras. 2.ed. Rio de Janeiro: Araújo Penna, p192-195.

Reis AA, Mendes CC, Ferraz TPL, Roque NF 2003. Terpenes from Mikania hookeriana. Biochem System Ecol 31: 1061-1062.

Rüngeler P, Brecht V, Tamayo-Castillo G, Merfort I 2001. Germacranolides from Mikania guaco. Phytochemistry 56: 475-489.

Sá RCS, Leite MN, Reporedo MM, Almeida RN 2003. Evaluation of long-term exposure to Mikania glomerata (Sprengel) extract on male Wistar rats' reproductive organs, sperm production and testosterone level. Contraception 67: 327-331.

Silva ML, Luz AIR, Zoghbi MGB, Ramos LS, Maia JGS 1984. Essential oils of some amazonian Mikania species. Phytochemistry 23: 2374-2376.

Veneziani RCS, Oliveira DCR 1999. Cosntituents of Mikania glomerata Sprengel. Biochem System Ecol 27: 99-102.

Vermeulen JK, De Vries A, Schlingmann F, Remie R 1997. Food deprivation: common sense or nonsense? Anim Technol 48: 45-54.

Vilegas JHY, de Marchi E, Lanças FM 1997. Extraction of low-polarity compounds (with emphasis on coumarin and kaurenoic acid) from Mikania glomerata (Guaco) leaves. Phytochem Anal 8: 266-270.

World Health Organization 1994. Programme for control of diarrhoeal diseases - Ninth Programme Report 19921993. Geneva, WHO/CDD/94.46.

Wong CL, Way MK 1981. Effects of aspirin and paracetamol on naloxone reversal of morphine-induced inhibition of gastrointestinal propulsion in mice. Eur $J$ Pharmacol 73: 11-19.

Zamorano G, Catalán CAN, Díaz JG, Herz W 1995. Sesquiterpene dilactones from Mikania ypacarayensis. Phytochemistry 38: 1257-1260.

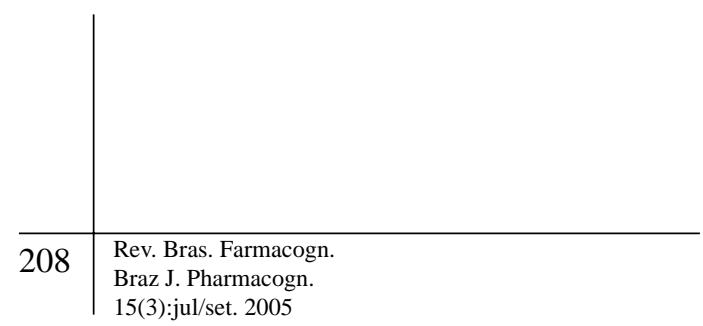

